\title{
LEARNED STAATSRECHT FROM THE HEARTLAND OF THE RECHTSSTAAT
}

\author{
Observations on the Significance of South African-German Interaction in \\ Constitutional Scholarship*
}

L du Plessis**

During (especially the latter half of) the previous century it was impressed on several generations of law students (mainly but not exclusively) at Afrikaans speaking law faculties in South Africa, to pride themselves on their "principled" legal education. ${ }^{1}$ Akin to (and indeed associated with) the paranormal knack of "thinking/reasoning like a jurist", principled legal thinking was not really taught (or learnt), but sustained (like injuries) as a result of exposure to principled law teachers, enhanced by the ambiance of a principle-prone law faculty. In the impressionable, young minds thus shaped Begriffsjurisprudenz was principled legal thinking incarnate, and Germany the Valhalla ${ }^{2}$ for those forever true to it.

* Background paper presented at a conference Public Law Themes in South Africa and Germany organised by South African scholars in Public Law under the auspices of the Alexander von Humboldt Foundation's regional "Humboldt-Kolleg" programme and held at the Stellenbosch Institute for Advanced Study, Stellenbosch from 8-10 September 2005.

** Professor of Public Law. University of Stellenbosch.

1 Especially in (substantive) criminal law and the various disciplines of (substantive) private law.

2 Lindemans 2002 http://www.pantheon.org/articles/v/valhalla.html 21 Nov:

"Valhalla, Hall of the Slain, in Norse mythology is the hall presided over by Odin. This vast hall has five hundred and forty doors. The rafters are spears, the hall is roofed with shields and breast-plates litter the benches. A wolf guards the western door and an eagle hovers over it. It is here that the Valkyries, Odin's messengers and spirits of war, bring half of the heroes that died on the battle fields (the rest go to Freya's hall Folkvang). These heroes, the Einherjar, are prepared in Valhalla for the oncoming battle of Ragnarok. When the battle commences, eight hundred warriors will march shoulder to shoulder out of each door." 
The so-called purist movement in South Africa, ${ }^{3}$ whose heyday more or less overlapped with that of the latter-day apartheid regime (1948-1994), bore the torch of principled legal scholarship and jurisprudence. Its adherents preached and promoted - in class but in time also in courtrooms - loyalty to pure RomanDutch law, untainted by English legal influence and unperverted by English minded judges' (mis-)understanding of it. Like the legal systems of the Romano-Germanic or civil-law legal family, Roman-Dutch law - the purists' source of and guide to principled legal thinking - is of learned Roman-law extraction. This accounts for the purists' heartfelt empathy with the (German) historical school and, eventually, with the nineteenth century Pandectists who strongly influenced key-facets of the private-law theory taught at Afrikaans speaking law faculties in South Africa. ${ }^{4}$

Traditional South African-German fellow-feelings in law remained restricted to private law (excluding formal private law), criminal law (excluding criminal procedure), legal history, Roman Law as an academic discipline and perhaps legal philosophy and legal theory too (with international law eventually also creeping into the picture) ${ }^{5}$ Conspicuously underrepresented on the affinity list, for a long time, was the public law relevant for us at this conference, namely constitutional and administrative law which, in the "old" South Africa, was much more English than Roman-Dutch - as was criminal and civil law of procedure and various branches of commercial law. Constitutional and political reform was at any rate not a foremost concern of prominent purist legal scholars in South Africa. The handful of pioneers concerned with such reform felt quite comfortable to seek comparative guidance in the constitutional law of the United States of America - the oldest example of a system of modern-day constitutional democracy. ${ }^{6}$

3 Cf in this regard Du Plessis Introduction to Law 57-63; Fagan "Roman-Dutch Law" 60-64.

4 For nuanced and insightful discussions of this influence cf Van der Walt 1996 TSAR (3) 521; Van der Walt 1996 TSAR (4) 626; Van der Walt 1992 THRHR 170.

5 For a helpful overview, relating to the Humboldt contribution in particular, cf Rabie, Van der Merwe and Labuschagne 1993 THRHR 608.

6 One of these scholars, John Dugard, thought that consistent reliance on the Roman-Dutch (common) law could have boosted the safeguarding of basic human rights in apartheid South Africa and that many of the ills of apartheid were attributable to a lack of rigorous reliance on this "rights-friendly" source of South African law: Dugard 1971 SALJ 181 and 
In the lively debates foreshadowing, accompanying and assessing the first tottering steps of constitutional democracy in South Africa during the 1990s, legal and constitutional comparison were dominant, and among the jurisdictions sourced for comparative examples Germany (and Canada) suddenly moved to the forefront. A number of South African scholars writing about various aspects of our transition to democracy, professed indebtedness to German sources, but not necessarily because these sources breathe the spirit of principledness. ${ }^{7}$ For the past ten years or so constitutional scholars have not (re-)turned to "the German example" as source of comparative information with an intensity and enthusiasm paralleling that of the mid-nineties. Most comparative studies referring to Germany ${ }^{8}$ actually saw the light when South Africa's transitional or interim Constitution ${ }^{9}$ was still in force. ${ }^{10}$

The major object of this conference is to explore with (and for the benefit of) South African scholars, eligible for Von Humboldt stipends, possibilities for postdoctoral research in constitutional and administrative law in Germany. In this background paper I intend pursuing this object in mainly three ways (and not necessarily strictly in the sequence below):

- First, to explore the relevance of the German tradition of scholarship for South African legal scholars doing research on matters constitutional.

- Secondly, to reflect on possible reasons for strong South African-German affinities in matters constitutional.

Dugard Human Rights and the South African Legal Order 393 397. Dugard was educated at one of the (erstwhile?) bastions of "principled legal thinking" in South Africa, namely the Faculty of Law at the University of Stellenbosch.

7 Francois Venter's attempt to adapt nineteenth century pandectism's "principled" theoretical framework for (private-law) subjective rights to use in public law, was the exception and not the rule (cf Venter Publiekregtelike Verhouding) which attracted criticism; cf Van der Vyver "Doctrine of Private-law Rights" 208-209; Wiechers "Publieke Subjektiewe Reg" 270-291.

8 Among which an article by De Waal 1995 SAJHR 1 is foremost.

9 Constitution of the Republic of South Africa 200 of 1993.

10 There are, however, examples of more recently dated monographs broadly dealing with comparative issues and in which "the German example" receives its rightful attention; cf eg De Wet Constitutional Enforceability of Economic and Social Rights; Van der Walt Constitutional Property Clauses 121-163; Venter Constitutional Comparison. 
- Thirdly, to reflect on the consequences of the affinities above-said as they have manifested themselves in South Africa's two constitutional texts since 1994 and in our constitutional scholarship and jurisprudence. Here I shall mainly devote attention to some developments since the commencement of South Africa's "final Constitution"11 in 1997. However, at pains to preface rather than pre-empt deliberations on particular issues and themes, this third aspect of the paper will be restricted to bare essentials.

As far as the first two aspects of the paper are concerned, I intend sharing a moderate measure of personal experience too, and this will inevitably put an anecdotal spin on my presentation. I mention this principally to forewarn myself that a successful anecdote is one not centred on the person of the anecdotist, but on the illustrative value of the narrative involved. In case I am a failure as an anecdotist let me offer all those who are age-wise still eligible for a Humboldt stipend sound (anecdotal) advice right at the outset: Do not let the opportunity to apply for a Von Humboldt stipend go by default! Not following this advice was a rather regrettable mistake in my own academic career.

I have never counted myself among those South African legal scholars revering the conventional version of principled German (or, for that matter, South African) legal thinking. I have always found the legal positivism inherent in such thinking uninteresting, uninspiring and unimaginative. At the same time I have been attracted by - and, indeed, biased towards - the German intellectual tradition in general, especially in legal philosophy and legal theory, my default interests. German writings on philosophical and legal philosophical issues of interest to me, have mostly left me with a decidedly favourable impression of the quality of German scholarship, and I thank my understanding of topics as diverse as the evolution of early Greek natural law and the legal and political thinking of the church reformer, Jean Calvin, mostly to German sources. ${ }^{12}$ In

11 The Constitution of the Republic of South Africa 108 of 1996 (hereinafter referred to as the 1996 Constitution).

12 Like Wolf Griechisches Rechtsdenken and Wolf Das Problem der Naturrechtslehre in 
time (and in a growingly activist vein) some of the work of the Frankfurter Schule (the "Neo-Marxists" - as we used to call them) also shaped aspects of my philosophical thinking beyond repair. ${ }^{13}$

During the early 1990s the expectation of a new constitutional era in South Africa whetted my appetite for German constitutional law (and constitutional interpretation in particular) largely because of my previously positive encounters with "German learning". At that time some of the locally published work contemplating a constitutionally reborn South Africa, devoted considerable attention to post-World War II German expertise and experience. ${ }^{14}$ In the process of actual constitution-making - both during the multi-party negotiations preceding the adoption of the transitional Constitution in 1993 and, later, in the Constitutional Assembly where the final (1996) Constitution took shape - a "German presence" (eventually manifesting itself in both end products) was tangible.

There is no single explanation for the consequential German influence on constitution-making and the inception of constitutional democracy in South Africa. As suggested before conventional academic affinities in law do not quite explain this phenomenon (but are also not wholly unrelated to it). Mentally many white Afrikaans speaking South Africans in apartheid South Africa identified with the "Germanic" traits in the German Volksgeist. For a long time German was the third language of preference in many an Afrikaans medium, secondary school. Germanist fellow-feelings among some Afrikaners even engendered concurrence in the Nazi notion of "an Arian Herrnvolk", remarkably pulling itself up by its bootstraps after a devastating war - against demonic forces that many Afrikaners, at any rate, regarded as hostile to their cause too. I can recall witnessing, even in the mid-1970s, earnest holocaust denial by welleducated, intelligent, Afrikaans speaking colleagues in law. It was, however, not

respect of the first topic and Baur Gott, Recht und Weltliches Regiment im Werke Calvins in respect of the second.

13 Cf eg Du Plessis 1984 THRHR 127.

14 Cf eg Davis, Chaskalson and De Waal "Democracy and Constitutionalism" 1-130. 
these ill-placed, pro-German sentiments that brought the markedly German element to the constitutional negotiating table in South Africa.

As apartheid South Africa faced increasing academic isolation, most German institutions involved in academic exchange (universities as well as funding organisations) continued "to provide and keep open channels for comparative research to South African jurists" ${ }^{\prime 15}$ irrespective of race, colour, gender or creed as well as, controversially so, political and institutional affiliation. In the case of Humboldt stipends in law, almost only white, male academics, some approaching and others negotiating midlife, were advantaged by this approach, the only exception being a white female academic in $1986 .^{16}$ The statistics for other German organisations, supporting academic exchange in law financially, probably did not differ significantly. According to the authors of an article appreciative of the Humboldt Foundation's contribution to the development of the South African legal system and legal literature (hereinafter "the Humboldt article") free access to the German academic world, amid increasing academic isolation elsewhere, resulted in "many South African jurists" relying "less heavily on Anglo-American law for comparative analysis" as well as a markedly "positive influence by German law on South African law reform". ${ }^{17}$ This last claim will be tested shortly. However, it can safely be assumed that the jurists above-said could not, by themselves, have paved the way for a marked German impact on constitutional developments in South Africa, simply because they lacked the political clout to determine the outcome of decisions during multi-part negotiations (in 1993) and in the Constitutional Assembly (between 1994 and 1996).

The "mighty" ANC relied heavily on the input of their German Berater, HansPeter Schneider, Director of the Deutsches Institut für Föderalismusforschung e.V. in Hannover, and Professor of Law at the University of Hannover until

15 Rabie, Van der Merwe and Labuschagne 1993 THRHR 622.

16 The position just sketched, is as it was until 1995 (more or less also the time when the academic isolation ended); cf Rabie, Van der Merwe and Labuschagne 1993 THRHR 610613.

17 Rabie, Van der Merwe and Labuschagne 1993 THRHR 622. 
2002. ${ }^{18}$ Schneider had also been (and I presume still is) a principal adviser to the SPD, the social-democratic ANC's kindred soul in Germany. The Democratic Party (as it then was ${ }^{19}$ ) found a congenial spirited adviser in Ingo von Münch, formerly Professor of law at the University of Hamburg, and active politician in the German FDP. Quite significantly the predominantly black ANC and the more English oriented DP relied more intensely on the input of German advisers than the Afrikaans oriented NP or Freedom Front.

Among the South African technical advisers closely involved in constitutionmaking during the 1990s, there were at least five Humboldt stipendiaries. Working in concert with German law advisers these South Africans were indeed favourably placed to bring on the "positive influence" of German constitutional law in the law reform in South Africa attendant on constitution-making. It is difficult to determine empirically to what extent this indeed happened, but circumstantial evidence points to the likelihood that German (constitutional) law indeed influenced law reform in South Africa in the manner envisaged by the authors of the Humboldt article.

Predominantly logistic reasons for South African-German interaction in the field of constitutional law and practice have been considered so far. However, what destiny had in store for both countries and both nations, especially during the latter half of the twentieth century, also served to forge an affectionate sense of understanding between them (vast dissimilarities notwithstanding). Germany is an example of a relatively young (post-World War II) democracy from whose experience we in a new South Africa in the making stood to learn a lot. ${ }^{20}$ The

18 Cf eg the contributions of Du Plessis "South Africa's peaceful Revolution" 209-224 and Steyler "Constitutional Promise of Decentralization in Practice" 225-240 in which they reminisce about issues in respect of which Schneider rendered valuable advice.

19 Presently the Democratic Alliance (DA).

20 On 11 September 1995 the former president of South Africa, Nelson Mandela, in his address at a state banquet in honour of former German chancellor, Helmut Kohl, then officially visiting South Africa, for instance said the following: 
constitutions of the vast majority of African states as well as, for instance, the Canadian Charter of Rights and Freedoms of course also date from the postWorld War II era. However, the German and South African experiences (put next to each other) stand out because of the matchless sense of urgency that, in both cases, permeated constitution-making and the establishment of constitutional democracy. The "Nicht wieder!" from post-Holocaust Germany reverberated (and indeed inspired action) in post-apartheid South Africa. In both countries far-reaching reconciliation and extensive nation-(re-)building simply had (and still has) to succeed to turn calamities of a shady past into accomplishments of a sunny future. The last step of constitutional significance in the German transition to full democracy, the Wiedervereingung, preceded the first step in the South African transition, the commencement of the transitional Constitution and the first democratic elections, by a mere three and a half years, and both moves were bolstered - or occasioned, some might say - by the same historical event(s): the decline of Communist hegemony in the East Block. South Africans and Germans can furthermore, without compromising the modesty becoming citizens of countries that could (still) have been in tatters, celebrate appreciable achievements along the road of constitutionalism so far achievements that add to the worthwhileness of Germany and South Africa as examples for constitutional comparison.

III

From experience I can say that in the realm of public law scholarship in Germany the phenomenon going by the name "typical German" is rather

\footnotetext{
"We know that the challenges facing South Africa today are in many ways comparable to those that faced Germany after the Second World War. In as much as we benefited immensely from the support of the German people in the struggle against apartheid, we can learn much by drawing on your valuable experiences in reconstruction and development.

The German constitution has, for example, become a popular reference point for South African experts. We believe we can learn much from Germany in the field of combating crime. Above all, history has placed economic reconstruction and national reconciliation at the centre of the challenges faced by both countries." (see ANC 1995 http://www.anc.org.za/ancdocs/history/mandela/1995/sp950911.html 21 Nov).
} 
elusive - especially the "typical German intellectual/professor". Typicalness in German legal scholarship is (typically) associated with the "principled legal thinking" of Begriffsjuriprudenz, ${ }^{21}$ perceiving the law as a self-contained, rational system of general norms. Legal problems are solved when, through deductive reasoning, a concrete situation is subsumed under a norm appropriate to the exigencies of that type of situation. The state is the source of law and law, in its turn, allegedly rests on an independent foundation of reason and logic. Courts are autonomous institutions that apply the law in a systematic (even mechanistic) way as if it were a system of fixed (and predictable) rules. The "is" and the "ought" of law are markedly distinct, as are "law" and "morality" as well as "law" and "politics".

German public lawyers working with the Basic Law can hardly afford to buy into the conventional paradigm just described. The Basic Law perceives fundamental rights as anterior to the state and "the state's law" as subject to the objective order of values enshrined in the Basic Law. Law and morality (and law and politics) can therefore not "neatly" be separated. However, to quote Donald Kommers, ${ }^{22}$ "the approach to judicial reasoning in Begriffsjurisprudenz has outlasted positivism and has had a lasting influence throughout Europe, including Germany ... German constitutional scholars no less than the justices of the Federal Constitutional Court have made significant attempts to build a theory of judicial decision based on reason and logic." I think this explains the resoluteness with which even the freest thinkers among the German colleagues in public law I have encountered, can proffer answers to certain questions of law as if the law as it stands is (and can be) uncontentious. The more tentative manner in which South African scholars typically respond when interrogated about the law as it stands, evidences that we are partially made of common law stuff - always ready to defer to any last word that a judicial authority might (for the time-being) have.

21 For a succinct depiction of this style of thinking, cf Kommers Constitutional Jurisprudence 40-41.

22 Kommers Constitutional Jurisprudence 41. 
The observations of Kommers also go some way to explain a phenomenon that took me by some surprise when I first came across and reflected on it, and that has ever since intrigued me - (also) because German constitutional scholars take it so much for granted that it is hard to find anyone who cares to explain (let alone justify) it. I refer here to the unquestioned use of FC Von Savigny's ${ }^{23}$ four "methods of interpretation" for purposes of constitutional interpretation. Also known as the "Von Savigny quartet" ${ }^{24}$ these so-called methods were initially designed for the interpretation of pandectaerian Roman law, but in time they have gained acceptance all over the European Continent, ${ }^{25}$ for the interpretation of codifications of the law, statutes ${ }^{26}$ and constitutions. ${ }^{27}$ In the South African context Hahlo and Kahn ${ }^{28}$ first referred to them and since 1994 they have also met with (extra-judicial) approval. ${ }^{29}$ These methods or modes of interpretation or, more appropriately, reading strategies - Labuschagne ${ }^{30}$ speaks of angles of incidence ("invalshoeke") - modelled on a slightly adapted version of the Savignian model, ${ }^{31}$ are:

- grammatical interpretation concentrating on ways in which the conventions of natural language can assist legal interpretation and can help to limit the many possible meanings of a provision;

23 Von Savigny System des heutigen Römischen Rechts 206-262.

24 Labuschagne 1983 THRHR 422 and Labuschagne 2004 THRHR 4346.

25 But also in the civil law tradition in Canada; cf eg Côté The Interpretation of Legislation in Canada 193-350.

26 Cliteur Inleiding in het Recht 196-202; Labuschagne 2004 THRHR 4346.

27 Forsthoff Zur Problematik der Verfassungsauslegung 39-40; Hesse Grundzüge des Verfassungsrechts der Bundesrepublik Deutschland 21; Kommers Constitutional Jurisprudence 42-43; Müller and Christensen Grundlagen Öffentliches Recht 269-297; and Müller 1999 Stell LR 275-276. Brugger 1994 Archiv des Öffentlichen Rechts 1-34 redefines the four methods or techniques of interpretation in a creative manner so as to adapt them to his understanding of the modern-day exigencies of (constitutional) interpretation.

28 Hahlo and Kahn South African Legal System 180.

29 Currie and De Waal Bill of Rights Handbook 145-156 rely, for purposes of bill-of-rights interpretation, on an interpretive scheme akin to that of Von Savigny System des heutigen Römischen Rechts 206-262. See also Du Plessis 1998 Acta Juridica 13-16.

30 Labuschagne 2004 THRHR 4346.

31 For a summary see Du Plessis 1998 Acta Juridica 8. 
- systematic interpretation, as a manifestation of contextualism, ${ }^{32}$ calling for an understanding of a specific provision in the light of the text or instrument as a whole and of extra-textual indicia;

- purposive interpretation ${ }^{33}$ that sheds light on the possible meanings of a provision with reference to its purpose or ratio, and

- historical interpretation situating a provision in the tradition from which it emerged and allowing qualified recourse to information concerning the genesis of the text in which the provision occurs (and concerning the provision itself). ${ }^{34}$

In short, I think Savigny's four "methods of interpretation" have found acceptance in German constitutional interpretation because (and simply because) their "reason and logic" (and "pedigree", one might perhaps add) appeal to constitutional scholars and judges (as jurists).

IV

Constitutional-law scholarship in Germany is vast, has a long history and accommodates - as is to be expected - diverse and divergent shades and styles of thinking. Endeavouring to discern a mainstream is contentious.

By way of example, fairly representative I trust, I wish to give a brief account of my impressions and experiences when I first spent time in Germany some ten years ago, doing comparative research as part of a project entitled Statutory Interpretation in South Africa in the Light of the Adoption of a Bill of Rights. ${ }^{35}$ My aim was to complete a literature study, reading and collecting materials, making them accessible for later use and compiling a list of available literature

32 Du Plessis (Re-)Interpretation of Statutes 111-115.

33 As manifestation of interpretive purposivism, see Du Plessis (Re-)Interpretation of Statutes 115-119.

34 In the course of time a fifth "method" was added to the Von Savigny quartet, namely comparative interpretation, which facilitates the understanding of a provision, first, in the light of standards of international law and, secondly, in comparison with its counterparts in other national legal systems.

35 My unpublished report on the project was written in Afrikaans: Wetsuitleg in Suid-Afrika in die Lig van die Aanvaarding van ' $n$ Menseregtehandves. 
on my topic. Buzzwords for my study were "constitutional interpretation" (Verfassungsinterpretation/-auslegung) and "statutory interpretation" (Gesetzesinterpretation/-auslegung). Normally one would start reading about one's topic(s) in inclusive works in the field (Staats-/Verfassungsrecht) which, in the German context, means beginning with constitutional law textbooks (Lehrbücher ${ }^{36}$ and then, for more detail, moving to Basic Law commentaries. ${ }^{37}$ For my particular topic(s) it was important also to consult some standard works on legal methodology (Rechtsmethodenlehre). ${ }^{38}$ As one reads through these general sources, unignorable publications pertinent to more specific aspects of one's research topic start surfacing - often in the form of collective works in which "the best on the topic" has been included, ${ }^{39}$ but it can also be in the form of journal articles of restricted scope but lasting effect. For instance, the function, status and limits of theories and methods of (constitutional) interpretation (and of theories and methods of interpretation vis-à-vis one another) can, for instance, be problematic. ${ }^{40}$ In the German context ErnstWolfgang Böckenförde has, in the form of two relatively short but widely cited articles, made valuable (pioneering) contributions by duly distinguishing the respective interpretive roles of methods (and principles) of constitutional interpretation, on the one hand, and fundamental rights theories, on the other. ${ }^{41}$

36 Examples are Benda, Maihofer and Vogel (eds) Handbuch des Verfassungsrechts; Von Münch Staatsrecht; Hesse Grundzüge des Verfassungsrechts der Bundesrepublik Deutschland; Arnim Staatslehre der Bundesrepublik Deutschland; Maunz and Zippelius Deutsches Staatsrecht; Stein Staatsrecht.

37 Eg Sachs (ed) Grundgesetz Kommentar; Stern Das Staatsrecht der Bundes-republik Deutschland; Isensee and Kirchhof (eds) Handbuch des Staatsrechts der Bundesrepublik Deutschland; Wassermann (ed) Kommentar zum Grundgesetz. There is even the odd constitutional law casebook: Richter and Schuppert Casebook Verfassungs-recht.

38 Here the work of Müller and Christensen Grundlagen Öffentliches Recht dealing particularly with the methodology of public law, is indispensible. They have recently also published a second volume in which they apply their methodology in the context of European law: Müller and Christensen Europarecht. Classics on legal methodology include Coing Juristische Methodenlehre; Engisch Einführung in das juristische Denken; Larenz Methodenlehre der Rechtswissenschaft; Schmalz Methodenlehre für das Juristische Studium; Zippelius Juristische Methodenlehre.

39 In respect of my research theme Dreier and Schwegmann (eds) Probleme der Verfassungsinterpretation, for instance, stood out.

40 As Michelman 1995 SAJHR 482-485 shows.

41 Böckenförde 1974 NJW 1529 and Böckenförde 1976 NJW 2089. 
In my field I have also come across work of German colleagues, creative in itself, and with catalytic qualities to unleash creative potential in others too. Examples are:

- the work of Peter Häberle exploring the idea of "the constitution as an open process"; 42

- Friedrich Müller's strukturierende Rechtlehre which is post-structuralism incarnate - with German consistency and precision, ${ }^{43}$ and

- Gerhard Robbers' knack of bringing (in his teaching and writing) constitutional ideas to life through appreciation of music, architecture and the plastic arts. ${ }^{44}$

I mention these examples so as to confront the stereotyped perception that the work of German constitutional law scholars, though thorough and meticulously systematic, is mostly tedious and uncreative.

\section{V}

Let me, in conclusion and as but a curtain raiser to the deliberations that are to follow, briefly take stock of what has happened to provisions of German origin in the South African Constitution - using the 1996 text as point of reference.

There is a sense in which the 1996 South African Constitution bears a stronger German resemblance than the 1993 (transitional) Constitution. Section 1 of the former arguably fulfils a role similar to article 20 of the German Basic Law (albeit not in similar terms), namely to characterise the kind of state for which the Constitution provides:

The Republic of South Africa is one, sovereign, democratic state founded on the following values:

42 Häberle Verfassung als Öffentlicher Prozeß.

43 Müller and Christensen Grundlagen Öffentliches Recht; for a compact version of the strukturierende Rechtslehre cf Müller 1999 Stell LR 269-283.

44 Robbers "Musik und Verfassung" 197-218. 
(a) Human dignity, the achievement of equality and the advancement of human rights and freedoms.

(b) Non-racialism and non-sexism.

(c) Supremacy of the constitution and the rule of law.

(d) Universal adult suffrage, a national common voters roll, regular elections and a multi-party system of democratic government, to ensure accountability, responsiveness and openness.

Article 20 of the basic law states that:

(1) The Federal Republic of Germany is a democratic and social Federal state.

(2) All state authority emanates from the people. It is exercised by the people by means of elections and voting and by separate legislative, executive and judicial organs.

(3) Legislation is subject to the constitutional order; the executive and the judiciary are bound by the law.

(4) All Germans shall have the right to resist any person seeking to abolish this constitutional order, should no other remedy be possible. $^{45}$

Of the pentarchy Parteienstaat, Rechtsstaat, Streitbare Demokratie, Sozialstaat and Bundesstaat envisaged in article 20 of the Basic Law, at least the first three are also "appointed" (and I guess one could add "anointed") by section 1 of the South African Constitution to shape the nature of the polity. What section 1(d) prescribes is certainly a party state and a competitive democracy, while "rule of law" in section 1(c) is the English common law way of saying "Rechtsstaat", though the two are not exactly synonyms. ${ }^{46}$ That South Africa is a social state is not really stated in section 1 , but it follows by necessary implication from several other constitutional provisions, for example, from section 7(2) that enjoins the state to "promote and fulfil" the rights in the Bill of Rights, from the

45 "(1) Die Bundesrepublik Deutschland ist ein demokratischer und sozialer Bundesstaat.

(2) Alle Staatsgewalt geht vom Volke aus. Sie wird vom Volke in Wahlen und Abstimmungen und durch besondere Organe der Gesetzgebung, der vollziehenden Gewalt und der Rechtsprechung ausgeübt.

(3) Die Gesetzgebung ist an die verfassungsmäßige Ordnung, die vollziehende Gewalt und die Rechtsprechung sind an Gesetz und Recht gebunden.

(4) Gegen jeden, der es unternimmt, diese Ordnung zu beseitigen, haben alle Deutschen das Recht zum Widerstand, wenn andere Abhilfe nicht möglich ist."

$46 \mathrm{Cf}$ eg the discussion of the Constitutional Court's jurisprudence on the rule of law in Currie and De Waal The new Constitutional and Administrative Law 75-81. 
authorisation of affirmative action in section 9(2), from the entrenchment of socio-economic entitlements (albeit restrained) in (amongst others) sections 26 and 27 and last but not the least from the jurisprudence of the Constitutional Court, construing these and other similar provisions. ${ }^{47}$ It is no secret that for historical reasons prominent South Africans at the helm of constitution-making and, subsequently, government in this country, do not cherish federalist sentiments akin to those of their German counterparts. It is therefore not surprising that section 1 of the South African Constitution does not describe South Africa as a federal state. At the same time South Africa is not anti-federal and can best be described as a co-operative as opposed to a competitive federation. $^{48}$ A principle that in Germany is meant to counteract the fragmentation of the federation, is invoked in South Africa to impel co-operation among the various spheres of government. This principle, of course, is the German notion of Bundestreue which, in Chapter 3 of the South African Constitution, goes by the name of "co-operative government". On an official visit to South Africa in September $1995^{49}$ former German chancellor, Helmut Kohl, invited South Africa's constitution-makers to send a delegation to Germany to study aspects of German constitutionalism. A multi-party delegation, consisting mainly of members of the National Assembly and advisers, visited Germany from 8 to 15 January $1996 .{ }^{50}$ One of the outcomes of this visit was that German ideas on federalism were included in South Africa's 1996 constitutional text without, however, fully embracing the German system of federalism whose centrifugal impetus is arguably more powerful than that of the South African system.

47 Government of the Republic of South Africa v Grootboom 2000 (11) BCLR 1235 (CC) and Treatment Action Campaign v Minister of Health (1) 2002 (10) BCLR 1033 (CC)

$48 \mathrm{Cf}$ eg the discussion of the Constitutional Court's jurisprudence on the rule of law in Currie and De Waal The new Constitutional and Administrative Law 119-124.

49 See $\mathrm{n} 20$ above.

50 For a reference to this visit, cf ANC 1998 http://www.anc.org.za/people/delange.html 21 Nov (parliamentarian and deputy-minister Johnny de Lange's curriculum vitae). I am also indebted to Prof Francois Venter of the North-West University, Potchefstroom, who provided me with an oral account of this visit and its consequences. 
Anyone conversant with the German Basic Law and the foundational prominence it affords human dignity, will be struck by the statement in section 1(a) of the South African Constitution that human dignity, together with the achievement of equality and the advancement of human rights and freedoms is one of the founding values of the Republic of South Africa as "one, sovereign, democratic state". References to human dignity also occur in certain pivotal provisions in the Bill of Rights (chapter 2 of the Constitution):

- Section 7(1) states that the Bill of Rights "affirms the democratic values of human dignity, equality and freedom".

- The general limitation clause, section 36, requires limitations of rights entrenched in the Bill of Rights to comply with the threshold of (amongst others) the extent to which the proposed limitation "is reasonable in an open and democratic society based on human dignity, equality and freedom". 51

- In section 39(1)(a) judicial authorities interpreting the Bill of Rights are enjoined "to promote the values that underlie an open and democratic society based on human dignity, equality and freedom".

The occurrence of the triumvirate of human dignity, equality and freedom in several places in the 1996 Bill of Rights tells where we in South Africa were coming from when we first tried to establish our fledgling constitutional democracy - exactly what article 1 of the Basic Law does with reference to Germany's unique (and sad) holocaust history. Comparable provisions in South Africa's transitional Bill of Rights mentioned freedom and equality, but not dignity. In human rights discourse and practice there is a perennial tension between freedom and equality, especially in a society like South Africa where astounding disparities between the haves and have nots still prevail. To the haves, on the one hand, their freedom is a vital item in the arsenal of whatever 
empowers them to have ever more. They are particularly mistrustful of government interfering in their affairs. The have nots, on the other hand, demand government intervention to empower them to gain a rightful share in the country's wealth - and this threatens the position of the haves in whom most of the wealth resides. It was therefore eminently sensible of the authors of the 1996 Constitution to come up with a textual strategy that can help negotiate the seemingly insoluble tension between freedom and equality: the inclusion in the constitutional sections referred to above of the value of human dignity with its particular history (also and especially in Germany) curbs the tendency to over-concentrate attention - in an "either . . . or" manner - on the fear of the haves and the plight of the have nots, and it demands deference to the worth and eminence of both the have nots and the haves as dignified human beings.

\section{VII}

Section 39(2) of the South African Constitution enjoins the judiciary, "[w]hen interpreting any legislation and when developing the common law or customary law" to "promote the spirit, purport and objects of the Bill of Rights". Looked at superficially, this may seem to be a rather trite (and therefore superfluous) injunction. However, not only does this provision have a fascinating history, but it has also become a kingpin in the evolution of South African law. At the 1993 multi-party negotiations there was a strong sentiment against direct horizontal application of the Bill of Rights. It came from (amongst others and strangely enough) the representatives of the South African Communist Party. After an intense and lively debate in which the German notions of mittelbare and unmittelbare Drittwirkung featured freely and prominently, a compromise was reached and subsequently written into sections 7(1) and (2) of the transitional Constitution. The said section left room for a restrictive understanding of the operation of the Bill of Rights, excluding its direct horizontal effect. This was also how the section was eventually construed in the then landmark (and now almost forgotten) Constitutional Court judgement of Du Plessis and Others $v$ De 
Klerk and Another. ${ }^{52}$ Part of the package of the section 7 deal was the inclusion in the transitional Constitution of section 35(3), the predecessor to section 39(2) of the 1996 Constitution, in an attempt to ensure that the provisions of the Bill of Rights will at least have some "radiating effect" on the interpretation and application of non-constitutional law. The wording of the two consecutive provisions is very similar. That is, however, not the case with sections 7(1) and (2) of the transitional Constitution, and their successors in the 1996 Constitution, sections 8(1)-(3). The latter provisions authorise the direct horizontal application of "[a] provision of the Bill of Rights . . to the extent that it is applicable taking into account the nature of the right and the nature of any duty imposed by the right". There has not been a Du Plessis $v$ De Klerk on section 8 (yet), ${ }^{53}$ but there has in the meantime been a Carmichele $v$ Minister of Safety and Security and Another, ${ }^{54}$ a hurricane that could well be named Alix Jean after a very brave litigant, that has swept through our existing (common and especially private) law, with a force that initially seemed to have washed away all interest in the vexing (yet neglected) question posed by sections 8(1)(3) of the Constitution, namely: "Precisely how directly do horizontal provisions of the Bill of Rights apply?" In the meantime, however, in the case of Khumalo and Others $v$ Holomisa ${ }^{55}$ O'Regan j intimated that direct horizontal application of the Bill of Rights (to natural and juristic persons) is always a possibility, depending on the circumstances of each particular case, but section 8(3) of the Constitution requires any such application of a particular right in the Bill of Rights to be mediated by the common law. "Common law" can be the common law as it stands or the common law as developed by the court if the law as it stands does not adequately cater for the exigencies of the situation under consideration.

The Constitutional Court's judgement in Carmichele was not an interpretation and application of sections 8(1)-(3), but of section 39(2), and it has opened

52 Du Plessis v De Klerk 1996 (5) BCLR 659 (1996 (3) SA 850) (CC).

53 The way in which s 8 of the 1996 Constitution has been structured, arguably precludes the necessity of an effort as monumental as Du Plessis v De Klerk to unravel the mystery of horizontal application.

54 Carmichele v Minister of Safety and Security 2001 (10) BCLR 995 (2001 (4) SA 938) (CC).

55 Khumalo v Holomisa 2002 (8) BCLR 771 (2002 5 SA 401) (CC) par 31-34. 
floodgates of legal reform through judicial intervention to such an extent that it has probably become necessary to consider strategies to channel the flood. A possible strategy, which our Constitutional Court has invoked without naming it, is what has become famous in Germany (and all of Europe) by the name of subsidiarity. In S v Mhlungu and Others ${ }^{56}$ subsidiarity "made in South Africa" was verbalised as follows:

I would lay it down as a general principle that where it is possible to decide any case, civil or criminal, without reaching a constitutional issue, that is the course which should be followed.

In some of my own writings I have proposed an adaptation of subsidiarity for use in the South African context. ${ }^{57}$ I leave the detail for another occasion. It is important for the present to note that this is an area for very fruitful co-operation with our German counterparts in public law and probably also European law given the history of section 39(2) as product of a Drittwirkung debate.

\section{VIII}

The transitional Constitution contained three provisions that were eventually excluded from the 1996 Constitution. Two of them, sections 35(2) and 232(3) prescribed a widely acknowledged interpretive procedure, known as verfassungskonforme Auslegung in the German context, for the interpretation of, respectively, the Bill of Rights and the Constitution as a whole. The omission of these two provisions from the 1996 Constitution did not preclude judicial reliance on the interpretive procedure they (previously) prescribed $^{58}$ and verfassungskonforme Auslegung is still very much part of our constitutional law as it stands.

56 S v Mhlungu 1995 (7) BCLR 793 (1995 (3) SA 867) (CC) par 59.

57 Cf Du Plessis (Re-)Interpretation of Statutes 29-32.

58 Cf eg Govender v Minister of Safety and Security 2001 (4) SA 273 (SCA). 
More directly and exclusively German was the Wesensgehaltgarantie included in the general limitation clause ${ }^{59}$ in the transitional Bill of Rights. Like their German counterparts South African constitutional scholars and lawyers struggled to get to the heart of the essential content of rights and what added to our misery, on this side of the equator, was the fact that we took over a provision with a singular history and then ignored that history when we wrote in into our transitional Bill of Rights. I have not witnessed a single tear being shed over the demise of the Wesensgehaltgarantie in the 1996 Constitution.

\section{IX}

There is much for which we as scholars of and citizens under the South African Constitution can thank our German counterparts. Fortunately they are not in the bad habit of constantly reminding us of it. In the formerly referred to Humboldt article, the authors conclude: $:^{60}$

Over almost three decades, the Alexander von Humboldt Foundation has contributed substantially to the personal development and growth of a number of jurists who have, in turn, exercised a significant influence on both the theory and the practice of South African law. This the Foundation has achieved without endeavouring to transplant German legal doctrine on its South African counterpart. Rather, scholars have been enabled to develop their own legal thought and theory, and so to be part of the evolution of their legal system as they consider appropriate.

In my experience a similar spirit permeates interaction between South African and German scholars in matters constitutional. And I do not think that especially during the last ten to fifteen years it has been just a one way traffic: there is indeed much to be learnt from South Africa and especially from our constitutional enterprise of accommodating (and desiring to celebrate) our diversity as an asset. South Africa's "small miracle", à la Nelson Mandela, ${ }^{61}$ can

59 S 33(1)(b).

60 Rabie, Van der Merwe and Labuschagne 1993 THRHR 622.

61 Cf eg Lawrence "From Soweto to Codesa" 1. 
only be sustained if we do not take it for granted - and if we share its fruits with kindred spirits the world over. Humboldt exchanges contribute to a considerable extent to the creation of a supra-national context within which this can be done. 


\section{Bibliography}

Arnim Staatslehre der Bundesrepublik Deutschland

Arnim HH von Staatslehre der Bundesrepublik Deutschland (Vahlen

München 1984)

Baur Gott, Recht und Weltliches Regiment im Werke Calvins

Baur J Gott, Recht und Weltliches Regiment im Werke Calvins (Bouvier

Bonn 1965)

Benda, Maihofer and Vogel (eds) Handbuch des Verfassungsrechts

Benda E, Maihofer W and Vogel HJ (eds) Handbuch des

Verfassungsrechts $2^{\text {nd }}$ ed (De Gruyter Berlin 1995)

Böckenförde1976 NJW 2089

Böckenförde E-W "Die Methoden der Verfassungsinterpretation -

Bestandaufnahme und Kritik" 1976 NJW (29) 2089

Böckenförde 1974 NJW 1529

Böckenförde E-W 1974 "Grundrechtstheorie und Grundrechtsinterpretation" NJW (27) 1529

Brugger 1994 Archiv des Öffentlichen Rechts 1-34

Brugger, W "Konkretisierung des Rechts und Auslegung der Gesetze" 1994 Archiv des Öffentlichen Rechts (119) 1

Cliteur Inleiding in het Recht 196-202

Cliteur PB Inleiding in het Recht (Wolters-Noordhoff Groningen 1992)

Coing Juristische Methodenlehre

Coing H Juristische Methodenlehre (De Gruyther Berlin 1972) 
Côté The Interpretation of Legislation in Canada 193-350

Côté P-A The Interpretation of legislation in Canada (Yvon Blais

Cowansville 1984)

Currie and De Waal Bill of Rights Handbook

Currie I and De Waal J The Bill of Rights Handbook $5^{\text {th }}$ ed (Juta Kenwyn 2005)

Currie and De Waal The new Constitutional and Administrative Law 75-81 Currie I and De Waal J The new Constitutional and Administrative Law Volume 1 (Juta Lansdowne 2001)

Davis, Chaskalson and De Waal "Democracy and Constitutionalism" 1-130 Davis D, Chaskalson M and De Waal J "Democracy and constitutionalism: the role of constitutional interpretation" in Van Wyk D et al (eds) Rights and constitutionalism: the new South African legal order (Kenwyn Juta 1994)

De Waal 1995 SAJHR 1

De Waal J "A Comparative Analysis of the Provisions of German Origin in the Interim Bill of Rights" 1995 SAJHR (11) 1

De Wet Constitutional Enforceability of Economic and Social Rights De Wet E The Constitutional Enforceability of Economic and Social Rights (The meaning of the German Constitutional Model for South Africa) (Butterworth Durban 1996)

Dreier and Schwegmann (eds) Probleme der Verfassungsinterpretation Dreier R and Schwegmann F (eds) Probleme der Verfassungsinterpretation: Dokumentation e. Kontroverse (Nomos BadenBaden 1976)

Du Plessis 1998 Acta Juridica 8 Du Plessis LM "The Jurisprudence of Interpretation and the Exigencies of a new Constitutional Order in South Africa" 1998 Acta Juridica 8 
Du Plessis 1984 THRHR 127

Du Plessis LM “'n Regsorde sonder Norme? ('n Verkenning van normrelativerende Tendense in enkele irrasionalistiese Teorieë oor die Reg)“ 1984 THRHR 47 (2)

Du Plessis Introduction to Law Du Plessis LM An Introduction to Law $3^{\text {rd }}$ ed (Juta Kenwyn 1999)

Du Plessis (Re-)Interpretation of Statutes Du Plessis LM The (Re-)Interpretation of Statutes (Butterworth Durban 2002)

Du Plessis "South Africa's peaceful Revolution" 209-224 Du Plessis LM "South Africa's peaceful Revolution and its constitutional Safegaurding" in Kramer J and Schubert BG (eds) Verfassungsgebung und Verfassungsreform im In- und Ausland (Nomos Baden-Baden 2005)

Dugard 1971 SALJ 181

Dugard J "The Judicial Process, Positivism and Civil Liberty" 1971 SALJ 88

Dugard Human Rights and the South African Legal Order 393, 397

Dugard J Human Rights and the South African Legal Order (University Press Princeton 1978)

Engisch Einführung in das juristische Denken

Engisch K Einführung in das juristische Denken $8^{\text {th }}$ ed (Kohlhammer Berlin 1989)

Fagan "Roman-Dutch Law" 60-64

Fagan E "Roman-Dutch Law in its South African historical Context" in Zimmermann R and Visser D (eds) Southern Cross: Civil Law and Common Law in South Africa (Juta Kenwyn 1996) 33-64 
Forsthoff Zur Problematik der Verfassungsauslegung

Forsthoff E Zur Problematik der Verfassungsauslegung (Kohlhammer Stuttgart 1961)

Häberle Verfassung als Öffentlicher Prozeß

Häberle P Verfassung als Öffentlicher Prozeß: Materialen zu einer Verfassungstheorie der Offenen Gesellschaft (Duncker \& Humblot Berlin 1978)

Hahlo and Kahn South African Legal System 180

Hahlo HR and Kahn E The South African Legal System and its Background (Juta Cape Town 1973)

Hesse Grundzüge des Verfassungsrechts der Bundesrepublik Deutschland Hesse K Grundzüge des Verfassungsrechts der Bundesrepublik Deutschland $19^{\text {th }}$ ed (Müller Heidelberg 1993)

Isensee and Kirchhof (eds) Handbuch des Staatsrechts der Bundesrepublik Deutschland Isensee J and Kirchhof P (eds) Handbuch des Staatsrechts der Bundesrepublik Deutschland (Müller Heidelberg 1992)

Kommers Constitutional Jurisprudence

Kommers DP The Constitutional Jurisprudence of the Federal Republic of Germany $2^{\text {nd }}$ ed (University Press Durham 1997)

Labuschagne 2004 THRHR 43

Labuschagne JMT "Die dinamiese Regslandskap, Doelaanpassing en vervanging en die Geregtigheidswaarde van die Normdop by Regsuitleg en -vorming: Opmerkinge oor die anachronistiese kant van die Stelreël cessante ratione legis, cessat et ipsa lex" 2004 THRHR 67 (1) 43 
Labuschagne 1983 THRHR 422

Labuschagne JMT "Regsdinamika: Opmerkinge oor die Aard van die Wetgewingsproses" 1983 THRHR 46 (4)

Larenz Methodenlehre der Rechtswissenschaft

Larenz K Methodenlehre der Rechtswissenschaft $6^{\text {th }}$ ed (Springer Heidelberg 1991)

Lawrence "From Soweto to Codesa" 1-12

Lawrence R "Introduction: From Soweto to Codesa" in Friedman S and Atkinson D (eds) The South African Review 7. The Small Miracle. South

Africa's negotiated Settlement (Ravan Press Johannesburg 1994) 1-12

Maunz and Zippelius Deutsches Staatsrecht

Maunz T and Zippelius R Deutsches Staatsrecht: Ein Studienbuch $28^{\text {th }}$ ed (Beck München 1991)

Michelman 1995 SAJHR 477

Michelman FI "A Constitutional Conversation with Professor Frank Michelman" 1995 SAJHR 477

Müller 1999 Stell LR 269

Müller F "Basic Questions of Constitutional Concretisation" 1999 Stell LR 10 (3) 269

Müller and Christensen Europarecht Müller F and Christensen R Juristische Methodik Band II: Europarecht (Duncker \& Humblot Berlin 2003)

Müller and Christensen Grundlagen Öffentliches Recht Müller F and Christensen R Juristische Methodik Band I: Grundlagen Öffentliches Recht $8^{\text {th }}$ ed (Duncker \& Humblot Berlin 2002) 
Rabie, Van der Merwe and Labuschagne 1993 THRHR 608

Rabie A, Van der Merwe S and Labuschagne JMT "The Contribution of the Alexander von Humboldt Foundation to the Development of the South African Legal System and Literature" 1993 THRHR 56 (4) 608

Richter and Schuppert Casebook Verfassungsrecht

Richter I and Schuppert GF Casebook Verfassungsrecht $3^{\text {rd }}$ ed (Beck München 1996)

Robbers "Musik und Verfassung" 197-218

Robbers G "Musik und Verfassung" in Becker H-J (ed) Interdependenzen zwischen Verfassung und Kultur (Duncker \& Humblot Berlin 2003) 197-218

Sachs (ed) Grundgesetz Kommentar

Sachs M (ed) Grundgesetz Kommentar $3^{\text {rd }}$ ed (Beck München 2003)

Schmalz Methodenlehre für das Juristische Studium

Schmalz D Methodenlehre für das Juristische Studium $3^{\text {rd }}$ ed (Nomos Baden-Baden 1992)

Stein Staatsrecht

Stein E Staatsrecht $14^{\text {th }}$ ed (Mohr Tübingen 1993)

Stern Das Staatsrecht der Bundesrepublik Deutschland

Stern K Das Staatsrecht der Bundesrepublik Deutschland (Beck München 1994)

Steyler "Constitutional Promise of Decentralization in Practice" 225-240

Steyler N "The constitutional Promise of Decentralization in Practice: A

Review of 1994-2002" in Kramer J and Schubert BG (eds)

Verfassungsgebung und Verfassungsreform im In- und Ausland (Nomos

Baden-Baden 2005) 
Van der Vyver "Doctrine of Private-law Rights" 201-246

Van der Vyver JD "The Doctrine of Private-law Rights" in Strauss SA (ed)

Huldigingsbundel vir WA Joubert (Butterworth Durban 1988) 201-246

Van der Walt 1996 TSAR (3) 521

Van der Walt JWG "Skerwe uit die Geschichte van die Leerstuk van

Subjektiewe Regte - deel 1" 1996 TSAR (3) 521-537

Van der Walt 1996 TSAR (4) 626

Van der Walt JWG "Skerwe uit die Geschichte van die Leerstuk van

Subjektiewe Regte - slot" 1996 TSAR (4) 626-638

Van der Walt 1992 THRHR 170

Van der Walt AJ "Personal Rights and limited Real Rights: An historical

Overview and Analysis of contemporary Problems related to the

Registrability of Rights" 1992 THRHR 55 (2) 170

Van der Walt Constitutional Property Clauses

Van der Walt AJ Constitutional Property Clauses (Juta Kenwyn 1999)

Venter Constitutional Comparison

Venter F Constitutional Comparison: Japan, Germany, Canada and South

Africa as Constitutional States (Juta Lansdowne 2000)

Venter Publiekregtelike Verhouding

Venter F Die Publiekregtelike Verhouding (Butterworth Durban 1985)

Von Münch Staatsrecht

Von Münch I Staatsrecht $/ 6^{\text {th }}$ ed (Kohlhammer Stuttgart 2000)

Von Savigny System des heutigen Römischen Rechts 206-262

Von Savigny FC System des heutigen Römischen Rechts I (Veit Berlin 1840) 
Wassermann (ed) Kommentar zum Grundgesetz

Wassermann R (ed) Kommentar zum Grundgesetz für die Bundesrepublik Deutschland (Neuwied Darmstdadt Luchterhand 1984)

Wiechers "Publieke Subjektiewe Reg" 270-291

Wiechers M "Die Publieke Subjektiewe Reg" in Strauss SA (ed)

Huldigingsbundel vir WA Joubert (Butterworth Durban 1988)

Wolf Das Problem der Naturrechtslehre

Wolf E Das Problem der Naturrechtslehre (Müller Karlsruhe 1959)

Wolf Griechisches Rechtsdenken

Wolf E Griechisches Rechtsdenken III I (Frankfurt Klosterman 1954)

Zippelius Juristische Methodenlehre

Zippelius R Juristische Methodenlehre: Eine Einführung $6^{\text {th }}$ ed (Beck München 1994)

\section{Register of legislation}

Constitution of the Republic of South Africa 1996

Constitution of the Republic of South Africa 200 of 1993

\section{Register of cases}

Carmichele v Minister of Safety and Security and Another 2001 (10) BCLR 995 (2001 (4) SA 938) (CC)

Du Plessis and Others v De Klerk and Another 1996 (5) BCLR 659 (1996 (3) SA 850) (CC)

Govender v Minister of Safety and Security 2001 (4) SA 273 (SCA)

Government of the Republic of South Africa and Others $v$ Grootboom and

Others 2000 (11) BCLR 1235 (CC)

Khumalo and Others v Holomisa 2002 (8) BCLR 771 (2002 5 SA 401) (CC) 
S v Mhlungu and Others 1995 (7) BCLR 793 (1995 (3) SA 867) (CC)

Treatment Action Campaign and Others $v$ Minister of Health and Others (1) 2002 (10) BCLR 1033 (CC)

\section{Register of Internet resources}

ANC 1998 http://www.anc.org.za/people/delange.html 21 Nov

African National Congress 1998 Biographies of ANC leaders: Johnny de Lange [Found on Internet] http://www.anc.org.za/people/delange.html [Date of use 21 Nov 2005]

ANC 1995 http://www.anc.org.za/ancdocs/history/mandela/1995/sp950911.html $21 \mathrm{Nov}$ African National Congress 1995 ANC documents: History. Presidential Speeches. Speech at State Banquet for the German Chancellor Dr Helmut Kohl [Found on Internet] http://www.anc.org.za/ancdocs/history/mandela/1995/sp950911.html [Date of use 21 Nov 2005]

Lindemans 2002 http://www.pantheon.org/articles/v/valhalla.html 21 Nov Lindemans MF 2002 Valhalla [Found on Internet] http://www.pantheon.org/articles/v/valhalla.html [Date of use 21 Nov 2005] 